\title{
Hubungan Lama Pemakaian Kontrasepsi Suntik Depo Progestin Dengan Kenaikan Berat Badan di BPM Hj. Suprihatin Sidoarjo
}

\author{
Yefi Marliandiani \\ Tenaga Pengajar Prodi D III Kebidanan Universitas PGRI Adi Buana Surabaya
}

\begin{abstract}
ABSTRAK
Penelitian berjudul Hubungan Lama Pemakaian Kontrasepsi Suntik Depo Progestin Dengan kenaikan Berat Badan di BPM Hj. Suprihatin Sidoarjo dilatar belakangi oleh banyaknya akseptor KB suntik Depo Progestin yang mengalami peningkatan berat badan. Tujuan dari penelitian ini adalah menganalisis hubungan lama pemakaian kontrasepsi suntik depo progestin dengan kenaikan berat badan.

Dalam penelitian ini digunakan metode Analitik Cross Sectional, dengan populasi 343 akseptor KB suntik depo progestin, sampel 103 akseptor. Teknik sampling menggunakan consecutive random sampling, alat penelitian menggunakan kuesioner, analisa data menggunakan uji Chi-Square.

Hasil yang diperoleh yaitu pemakaian kontrasepsi suntik depo progestin di BPM Hj. Suprihatin pada September 2014 terbanyak yang menggunakan kontrasepsi suntik Depo Progestin $\geq 1$ tahun sebanyak 78 orang $(75,73 \%)$, akseptor yang mengalami peningkatan berat badan sebanyak 63 orang $(61.17 \%)$, berdasarkan hasil uji statistic Chi-Square dengan taraf signifikansi a 0.05 ada hubungan lama pemakaian kontrasepsi suntik depo progestin dengan kenaikan berat badan di BPM $\mathrm{Hj}$. Suprihatin Sidoarjo.

Kesimpulan penelitian, ibu yang menggunakan metode kontrasepsi suntik Depo Progestin mengalami peningkatan berat badan. Bidan meningkatkan system pendokumentasian agar tercatat dan terlaporkan semua efek samping yang terjadi pada klien. Dan bagi peneliti selanjutnya agar melakukan penelitian lebih lanjut.

Kata Kunci: Lama pemakaian depo progestin, peningkatan berat badan
\end{abstract}

\section{PENDAHULUAN}

Keluarga Berencana (disingkat KB) merupakan gerakan untuk membentuk keluarga yang sehat dan sejahtera dengan membatasi jumlah kelahiran. Pembatasan jumlah kelahiran yang bisa dilakukan yaitu dengan penggunaan alat-alat kontrasepsi atau dengan cara-cara tertentu. Di Indonesia gerakan keluarga berencana ini mulai dicanangkan pada akhit tahun 1970. Seiring dengan bertambahnya jumlah penduduk di Indonesia yang pada tahun 2010 sudah mencapai 237.556.363 orang, hingga saat ini Program Keluarga Berencana masih terus digalakan, hal ini untuk menekan tingginya laju pertumbuhan penduduk. Untuk hal tersebut pemerintah Indonesia telah mengambil langkah antisipasi yaitu dengan membentuk sebuah badan yang secara spesifik bertanggung jawab terhadap pengendalian pertumbuhan penduduk Indonesia, yaitu Badan Koordinasi Keluarga Berencana Nasional (BKKBN) yang resmi berdiri melalui Keputusan Presiden Republik Indonesia Nomor 8 tahun 1970.

Program Keluarga Berencana oleh pemerintah melalui BKKBN bertujuan agar keluarga sebagai unit terkecil kehidupan bangsa diharapkan dapat mewujudkan Norma Keluarga Kecil Bahagia Sejahtera (NKKBS) 
yang berorientasi pada pertumbuhan yang seimbang. Perencanaan jumlah keluarga dengan pembatasan kelahiran dapat dilakukan dengan penggunaan alat kontrasepsi. Adapun beberapa jenis alat kontrasepsi dapat dibagi menjadi 2 golongan yaitu alat kontrasepsi yang mengandung hormone dan alat kontrasepsi yang tidak mengandung hormone. Beberapa jenis alat kontrasepsi tersebut antara lain pil, suntikan, implant, alat kontrasepsi dalam rahim (AKDR), kondom, tubektomi dan vasektomi. Penggunaan kontrasepsi didominasi oleh alat kontasepsi jangka pendek, terutama suntikan, yang mencapai 31.9 persen (SDKI, 2012). Tingkat pemakaian metode $\mathrm{KB}$ jangka panjang (MKJB), yaitu IUD, implan, metode operasi pria (MOP/vasektomi) dan metode operasi wanita (MOWI tubektomi) hanya sebesar 10, 6 persen (SDKI, 2012).

Terdapat dua jenis metode kontrasepsi suntik, yaitu suntikan yang mengandung hormone kombinasi estrogen dan progesterone dan suntikan yang mengandung hormone tunggal progesterone saja, dari kedua jenis suntikan tersebut yang paling banyak diminati adalah suntikan yang mengandung hormone progesterone saja. Metode kontrasepsi suntik, baik yang mengandung hormone kombinasi maupun hormone tunggal, keduanya mempunyai cara kerja yang sama yaitu mencegah terjadinya ovulasi.

Alat-alat

kontrasepsi

merupakan alat untuk upaya mencegah bertemunya sel telur dan sel sperma agar tidak mengalami pembuahan. Sehubungan dengan hal tersebut, pemerintah telah menyediakan beberapa jenis alat kontrasepsi yang dapat dipakai oleh terutama sebagian besar wanita usia subur, yang penggunaannya dapat disesuaikan dengan kondisi tubuh penggunanya, sehingga alat kontrasepsi tersebut diharapkan dapat efektif dalam upaya mencegah kehamilan serta sedikit mungkin efek sámping yang dapat menimbulkan gangguan kesehatan yang lebih berat bagi penggunanya.

Dari berbagai alat kontrasepsi tersebut, tidak ada satupun yang dapat menjamin terhindarnya dari suatu efek samping yang mungkin terjadi. Oleh karena itu sebelum alat kontrasepsi tersebut digunakan oleh pasangan usia subur, maka terlebih dahulu dilakukan konseling agar dalam pemakaiannya dapat lebih efektif serta secara sadar klien mengerti dan memahami kemungkinan efek samping yang mungkin terjadi, serta tahu apa yang harus dilakukan.

Seperti yang telah disampaikan diatas bahwa salah satu kontrasepsi yang populer di Indonesia adalah kontrasepsi suntik, kontrasepsi suntik yang digunakan adalah Noretisteon enentat (NETEN), Depo Medroksiprogesterone Asetat (DMPA) dan Cyclofem. Kontrasepsi suntik memiliki kelebihan dan keterbatasan. Salah satu keterbatasan dari kontrasepsi suntik adalah adanya efek samping yang dapat berupa pertambahan berat badan dari berat badan pada kunjungan pertama. yang merupakan efek samping yang tersering dari pemakaian kontrasepsi suntik, utamanaya kontrasepsi suntik DMPA. Pertambahan berat badan disebabkan oleh peningkatan nafsu makan disertai peningkatan penimbunana simpanan lemak. Selain itu terdapat keluhan lain yaitu berupa perdarahan bercak (spotting) dan amenore, juga merupakan efek samping yang kejadiannya sering dikeluhkan oleh akseptor KB suntik 3 bulanan yaitu alat kontrasepsi suntik depo progestin.

Berdasarkan studi pendahuluan pada 10 orang akseptor KB suntik di BPM Suprihatin, Sidoarjo didapatkan keterangan yang dapat dilihat pada table berikut; 
Tabel 1.3 Keluhan pada pemakaian alat kontrasepsi suntik depo progestin di BPM Suprihatin Sidoarjo

\begin{tabular}{|l|c|}
\hline \multicolumn{1}{|c|}{ JENIS KELUHAN } & JUMLAH \\
\hline Amenorhea & 10 \\
\hline Kenaikan berat badan & 6 \\
\hline $\begin{array}{l}\text { Perdarahan bercak } \\
\text { (spoting) }\end{array}$ & 4 \\
\hline Tidak ada keluhan & 0 \\
\hline
\end{tabular}

Sumber : Data Primer melalui wawancara

Dari tabel di atas dapat dijelaskan bahwa keluhan pada akseptor KB suntik Depo progestin di BPM Suprihatin, Sidoarjo, dari 10 orang akseptor tidak ada satupun yang tidak mengalami efek samping, bahkan untuk efek samping amenore dialami oleh semua akseptor yaitu 10 orang $(100 \%)$, sedangkan kenaikan berat badan dialami oleh 6 orang $(60 \%)$, dan yang mengalami efek samping perdarahan bercak (spotting) dialami oleh 4 orang akseptor (40\%).

Berdasarkan uraian di atas masalah yang ada adalah bahwa semua pengguna alat kontrasepsi suntik depo progstin telah mengalami efek samping yang bervariasi, yaitu berupa amenore,,kenaikan berat badan, dan perdarahan bercak.

Untuk mendapatkan gambaran nyata tentang kejadian efek samping bagi pengguna alat kontrasepsi suntik depo progestin, maka peneliti ingin melakukan penelitian tentang hubungan antara lama pemakaian alat kontrasepsi suntik depo progestin dengan efek samping tersebut berupa kenaikan berat badan, dengan demikian akan diketahui seberapa besar hubungan tersebut. Sedangkan untuk efek samping perdarahan bercak dan amenore tidak dilakukan penelitian dikarenakan adanya keterbatasan peneliti.

\section{Perumusan Masalah}

Berdasarkan latar belakang yang telah diuraikan maka rumusan masalah adalah "Apakah ada -hubungan lama pemakaian kontrasepsi suntik depo progestin dengan kenaikan berat badan?

\section{METODE PENELITIAN}

A. Kerangka Konsep Penelitian

Kerangka konseptual dalam penelitian ini dapat digambarkan sebagai berikut:

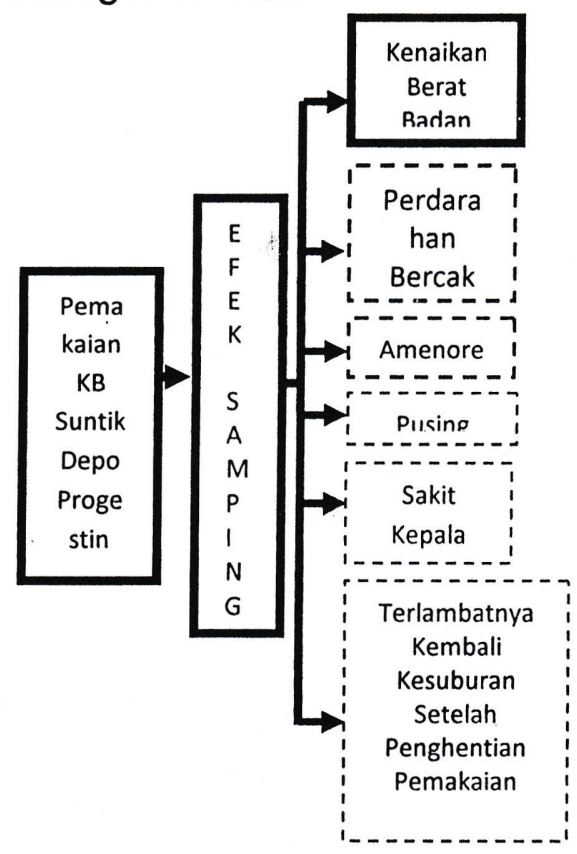

\section{Skema 3.1 Kerangka konseptual hubungan lama pemakaian kontrasepsi suntik Depo Progestin dengan beberapa jenis efek samping. .}

Dari kerangka konseptual di atas, dapat dilihat bahwa kontrasepsi suntik Depo Progestin dapat menyebabkan terjadinya efek samping berupa kenaikan berat badan, amenorrhea, spotting, menoraghia, pusing, sakit kepala dan terlambatnya kembali kesuburan setelah pemakaian. Pada penelitian ini, peneliti hanya meneliti tentang hubungan lama pemakaian kontrasepsi suntik Depo Progestin dengan keneikan berat badan dan perdarahan bercak. 


\section{B. Hipotesis}

Hipotesis penelitian adalah jawaban sementara terhadap masalah penelitian yang kebenarannya masih harus diuji dan dibuktikan dalam penelitian tersebut (Notoatmojo, 2012) dari kerangka konseptual diatas, hipotesis penelitiannya adalah "Apakah ada hubungan antara lama pemakaian kontrasepsi suntik Depo Progestin dengan peningkatan berat badan, dan perdarahan bercak?"

\section{Rancang Bangun Penelitian (Desain)}

Desain penelitian dalam penelitian ini adalah analitik dengan pendekatan Cross Sectional, yaitu data yang dikumpulkan sesaat atau data yang diperoleh pada satu saat. Penelitian ini bertujuan membuktikan hubungan lama pemakainan kontrasepsi suntik Depo Progestin dengan peningkatan berat badan, dan perdarahan bercak.

\section{Lokasi dan Waktu Penelitian}

\section{Lokasi Penelitian}

Penelitian

dilaksanakan di BPM Suprihatin Sidoarjo tahun 2014, adapun pemilihan lokasi tersebut didasarkan atas beberapa pertimbangan antara lain :

a. Kunjungan Akseptor KB suntik Depo Progestin cukup banyak yaitu $64 \%$ dari seluruh kinjungan pemakai alat kontrasepsi.

b. Yang bersangkutan bersedia kliennya dilakukan penelitian yang dibuktikan dengan memberi surat ijin untuk melakukan penelitian.

2. Waktu Penelitian

Penelitian ini dilaksanakan mulai bulan Agustus-September 2014

\section{E. Populasi}

Semua kunjungan baru akséptor kontrasepsi suntik Depo Progesti di BPM Suprihatin Sidoarjo, selama 1 tahun pada tahun 2013 sebanyak 343 orang

\section{F. Sampel}

Adapun Cara menentukan anggota sampel dalam penelitian ini yaitu dengan consecutive random sampling, yaitu pemilihan sampel dengan menetapkan subyek yang memenuhi kriteria penelitian dimasukkan dalam penelitian sampai kurun waktu tertentu sehingga jumlah sampel yang diperlukan terpenuhi, sedangkan pengambilan besar sampel yaitu ditentukan dengan menggunakan ketentuan bahwa jika besar populasi $\leq 1000$, maka besar sampel bisa diambil 20-30\% (Nursalam, 2003). Pada penelitian ini besar populasinya adalah 343 , peneliti mengambil $30 \%$ dari populasi, sehingga besar sampelnya adalah 103 orang.

\section{G. Instrumen Penelitian}

Dalam penelitian ini metode yang digunakan untuk mengumpulkan data adalah melalui wawancara terpimpin, dengan berpedoman pada kuesioner yang telah disusun dan disiapkan sebelumnya, sehingga interviewer tinggal membacakan pertanyaan-pertanyaan yang diajukan kepada responden untuk dijawab. Apabila responden merasa kurang jelas atas pertanyaan yang diajukan, maka interviewer menjelaskan maksud dari pertanyaan tersebut sampai responden mengerti dan dapat menjawab pertanyaan dengan pasti, dengan demikian peneliti memperoleh jawaban yang tepat.

\section{H. Pengumpulan Data Dan Pengolahan Data}

\section{Editing}

$$
\text { Editing adalah upaya }
$$


kebenaran data yang diperoleh atau dikumpulkan. Editing dilakukan pada tahap pengumpulan data atau setelah data terkumpul.

2. Coding

Coding merupakan kegiatan pemberian kode numeric atau angka terhadap data yang terdiri atas beberapa kategori. Pada penelitian ini pemberian kode pada pengolahan dan analisa data dilakukan dengan menggunakan komputer.

3. Analisis Data

kemudian Setelah data terkumpul pengolahan dilakukan pengorganisasian dan terakhir dilakukan uji statistik untuk mengetahui hubungan antara 2 variabel. Dalam penelitian ini dilakukan uji statistik yang sesuai yaitu dengan menggunakan uji Chi-Square, yaitu :

$$
X^{2}=\sum \frac{(f o-f h)^{2}}{f h}
$$

Dimana:

$X^{2}=$ Chi Kuadrat

fo $=$ frekuensi yang diperoleh berdasarkan data

fh = frekuensi yang diharapkan

Adapun derajat kemaknaan dari penelitian ini adalah 5\% ( $a=0,05)$. Berdasarkan perbandingan Chi - Square hitung dan Chi - Square tabel, jika Chi - Square hitung < dari Chi - Square tabel maka Ho diterima. Berarti tidak ada hubungan lamanya pemakaian KB suntik Depo Progestin dengan kenaikan berat badan, dan perdarahan bercak. Jika Chi - Square hitung > Chi Square tabel maka Ho ditolak berarti ada hubungan lamanya pemakaian KB suntik Depo Progestin dengan kenaikan berat badan, dan perdarahan bercak. Pada penelitian ini, setelah dilakukan analisa data dan dilakukan uji statistik ChiSquare menunjukkan bahwa HO ditolak, yang berarti ada hubungan antara lama pemakaian kontrasepsi suntik Depo Progestin dengan kenaikan berat badan dan perdarahan bercak. Untuk lebih jelasnya dapat dilihat pada bab Hasil Penelitian.

\section{Etika Penelitian}

Peneliti mendapat izin dari BPM Suprihatin Sidoarjo untuk melakukan penelitian khususnya pada ibu akseptor KB suntik Depo Progestin. Setelah mendapatkan izin, peneliti melakukan penelitian dengan menekankan masalah etika yang meliputi :

\section{Lembar Persetujuan}

Sebelum mengisi kuesioner, terlebih dahulu responden di minta kesediannya untuk menjadi responden yang dibuktikan dengan menandatangani surat persetujuan menjadi responden. Pada penelitian ini semua akseptor menyatakan setuju untuk menjadi obyek penelitian dengan membubuhkan tanda tangan tanda setuju pada lembar persetujuan untuk menjadi responden.

\section{Tanpa Nama (Anonimity)}

Untuk menjaga kerahasiaan identitas subyek, peneliti tidak mencantumkan nama subyek pada lembar pengumpulan data tetapi lembar tersebut hanya diberi kode tertentu.

\section{Kerahasiaan (Confidentiality)}

Kerahasiaan informasi responden dijamin oleh peneliti, hanya 
kelompok data tertentu yang dilaporkan sebagai hasil penelitian.

\section{HASIL PENELITIAN}

Pada bab ini akan disajikan hasil penelitian yang meliputi Hubungan Antara Lama Pemakaian Kontrasepsi Suntik Depo Progestin Dengan Kenaikan Berat Badan dan Perdarahan Bercak di BPM $\mathrm{H}$. Suprihatin Sidodadi Sidoarjo yang meliputi data umum dan data khusus.

\section{A. Data Umum}

Dari sejumlah akseptor KB suntik Depo Progestin didapatkan 103 orang yang terpilih sebagai responden dengan gambaran sebagai berikut:

\section{Distribusi}

\section{Responden}

Frekuensi

Umur

Tabel 4.1 Distribusi Frekuensi

Responden Berdasarkan Umur di BPM $H$. Suprihatin Sidoarjo

\begin{tabular}{ccc}
\hline Pendidikan & Jml & $\%$ \\
\hline$<20$ th & 1 & 0.97 \\
$20-35$ th & 70 & 67.96 \\
$>35$ th & 32 & 31.07 \\
\hline Jumlah & $\mathbf{1 0 3}$ & $\mathbf{1 0 0}$ \\
\hline \multicolumn{3}{c}{ Sumber: Data Primer 2014 } \\
\multicolumn{3}{c}{ Tabel 4.1 menunjukkan } \\
bahwa sebagian & besar \\
responden berumur & 20-35 \\
tahun (67.96\%)
\end{tabular}

2. Distribusi

Responden

Frekuensi

Pendidikan

Tabel 4.2 Distribusi Frekuensi

Responden Berdasarkan

Pendidikan di BPM $\mathrm{H}$.

Suprihatin Sidoarjo

\begin{tabular}{|c|c|c|}
\hline Pendidikan & Jumlah & $\%$ \\
\hline SD & 15 & 14.56 \\
\hline SLTP & 29 & 28.16 \\
\hline SLTA & 46 & 44.66 \\
\hline Akademi/PT & 13 & 12.62 \\
\hline Jumlah & 103 & 100 \\
\hline
\end{tabular}

Berdasarkan table 4.2 dapat dijelaskan bahwa dari 103 responden sebagian besar 46 responden $(44.66 \%)$ berpendidikan SLTA.

B. Data Khusus

1. Distribusi

Frekuensi

Responden

Berdasarkan

Lama Pemakaian Pada

Akseptor Kontrasepsi Suntik Depo Progestin

Tabel 4.3 Distribusi Frekuensi Responden Berdasarkan Lama Pemakaian Kontrasepsi Suntik Depo Progestin di BPM $H$. Suprihatin Sidoarjo

\begin{tabular}{|c|c|c|}
\hline $\begin{array}{c}\text { Lama } \\
\text { Pemakaian }\end{array}$ & Jumlah & $\%$ \\
\hline$<1$ tahun & 25 & 24.27 \\
\hline$>1$ Tahun & 78 & 75.73 \\
\hline Jumlah & 103 & 100 \\
\hline
\end{tabular}

Table 4.3 menunjukkan bahwa sebagian besar lama pemakaian kontrasepsi suntik Depo Progestin adalah lebih dari 1 tahun (75.73\%)

2. Distribusi

Frekuensi

Responden

Berdasarkan

Kenaikan Berat Badan Pada Akseptor Suntik Depo Progestin.

Tabel 4.4 Distribusi Frekuensi Responden Berdasarkan Kenaikan Berat Badan Pada Pemakaian Kontrasepsi Suntik Depo Progestin di BPM $\mathrm{H}$. Suprihatin Sidoarjo

\begin{tabular}{ccc}
\hline $\begin{array}{c}\text { Kenaikan } \\
\text { Berat } \\
\text { Badan }\end{array}$ & Jumlah & $\%$ \\
\hline Naik & 63 & 61.17 \\
Tidak Naik & 40 & 38.83 \\
\hline Jumlah & 103 & 100 \\
\hline Sumber: Data Primer 2014 &
\end{tabular}


(Vol.VI, Maret 2015 )

Table 4.4 menunjukkan bahwa sebagian besar akseptor KB Suntik Depo Progestin sebagian besar mengalami kenaikan berat badan yaitu sebanyak 63 orang

$(61.17 \%)$.

\section{Tabulasi Silang Antara Lama Pemakaian Kontrasepsi Suntik Depo Progestin Dengan Kenaikan Berat Badan}

Tabel 4.5 Tabulasi silang antara lama pemakaian kontrasepsi suntik Depo Progestin dengan kenaikan berat badan pada akseptor suntik Depo Progestin di BPM H. Suprihatin Sidoarjo.

\begin{tabular}{|c|c|c|c|c|c|c|c|}
\hline \multirow{3}{*}{ No } & \multirow{3}{*}{ Lama Pemakaian } & \multicolumn{4}{|c|}{$\begin{array}{c}\text { Kenaikan } \\
\text { BB }\end{array}$} & \multirow{3}{*}{$\begin{array}{c}\text { Jml } \\
\text { fo }\end{array}$} & \multirow[t]{2}{*}{$\%$} \\
\hline & & \multicolumn{2}{|c|}{ Naik } & \multicolumn{2}{|c|}{ Tidak Naik } & & \\
\hline & & fo & $f e$ & fo & $f e$ & & $f e$ \\
\hline 1 & $<1$ th & 10 & 15.29 & 15 & 9.71 & 25 & 24.27 \\
\hline 2 & $>1$ th & 53 & 47.71 & 25 & 30.29 & 78 & 75.73 \\
\hline & Jumlah & 63 & 63 & 40 & 40 & 103 & 100 \\
\hline
\end{tabular}

Sumber: Data Primer 2014

Tabel 4.5 dapat dijelaskan bahwa dari 103 responden, berdasarkan lama pemakaian kurang dari 1 tahun telah mengalami kenaikan berat badan sebanyak 10 orang $(9.71 \%)$, sedangkan yang lama pemakaian lebih dari 1 tahun yang mengalami kenaikan berat badan adalah sebanyak 53 orang $(51.46 \%)$.

\section{PEMBAHASAN}

\section{A. Lama Pemakaian Kontrasepsi Suntik Depo Progestin}

Berdasarkan table 4.3 dapat dijelaskan bahwa dari 103 responden yang terpilih, sebagian besar lama pemakaian kontrasepsi suntik Depo Progestin adalah lebih dari 1 tahun yaitu sebanyak 78 orang $(75.73 \%)$. Hal ini menunjukkan adanya kepuasan klien selama memakai alat kontrasepsi suntik Depo progestin. Metode-metode yang menuntut banyak dari pemakai, atau menimbulkan banyak efek samping yang harus ditoleransi pemakai, cenderung memiliki angka penghentian yang tinggi daripada metode yang tidak banyak menuntut (Glacier, 2006). Terdapat beberapa metode kontrasepsi lain yang angka penghentiannya cukup tinggi setelah pemakaian 1 tahun, diantaranya adalah metode barier sekitar $60 \%$, pantang berkala $40 \%$, pil sekitar 30\%, dan alat kontrasepsi dalam rahim (AKDR) sekitar 20\% (Glacier, 206).

Terdapat

beberapa pertimbangan lain bagi klien akseptor KB suntik depo progestin untuk tetap memakainya dalam jangka panjang, hal ini dikarenakan terdapat beberapa keuntungan yang menjadikan akseptor tetap memakai alat kontrasepsi tersebut, keuntungan tersebut adalah bahwa kontrasepsi suntik 3 bulan penggunaannya sangat praktis, efektif dan aman dengan tingkat keberhasilan lebih dari $99 \%$, tidak membatasi usia, dan cocok untuk ibu menyusui karena tidak mempengaruhi produksi air susu ibu (Irianto, 2014) 
B. Kenaikan Berat Badan Pada Akseptor Lama Suntik Depo Progestin

Tabel 4.4 menunjukkan bahwa sebagian besar akseptor mengalami kenaikan berat badan yaitu sebanyak 63 orang $(61.17 \%)$.

Terjadinya kenaikan berat badan kemungkinan karena hormone progesterone mempermudah perubahan karbohidrat dan gula menjadi lemak, sehingga lemak dibawah kulit bertambah. Selain itu hormone progesterone juga menyebabkan nafsu makan bertambah sedangkan aktifitas fisik menurun, akibatnya pemakaian suntikan hormone progesterone dapat menyebabkan berat badan bertambah (Irianto, 2014). Kenaikan berat badan ratarata setelah 1 tahun sekitar $2,5 \mathrm{~kg}$, setelah 2 tahun $3,8 \mathrm{~kg}$, setelah 6 tahun menjadi $7,5 \mathrm{~kg}$ (Sinclair, 2010). Umumnya pertambahan berat badan tidak terlalu besar, bervariasi antara kurang dari $1 \mathrm{~kg}$ sampai $5 \mathrm{~kg}$ dalam tahun pertama. Penyebab pertambahan berat badan tidak jelas. Namun bertambahnya lemak tubuh bukan karena retensi cairan tubuh. Hipotesa para ahli menunjukkan bahwa depomedroxi progesterone acetat merangsang pusat pengendali nafsu makan di hipotalamus, hal ini menyebabkan akseptor makan lebih banyak dari biasanya (Hartanto, 2004)

Terdapat beberapa informasi yang perlu diperhatikan oleh akseptor terhadap efek samping peningkatan berat badan, yaitu bahwa kenaikan berat badan 1-2 kg dapat terjadi pada tahun pertama pemakaian, klien perlu mengatur diet bila perubahan berat badan terlalu mencolok, dan bila berat badan sangat berlebihan, pemakaian bisa dihentikan dan dapat beralih kepada metoda kontrasepsi lain yang terpilih (Arum, 2011).

\section{Hubungan Antara Lama Pemakaian Kontrasepsi Suntik Depo Progestin Dengan Kenaikan Berat Badan}

Berdasarkan hasil tabulasi silang pada tabel 4.5 , yaitu antara lama pemakaian kontrasepsi suntik depo progestin dengan kenaikan berat badan, menunjukkan hasil bahwa dari 103 responden, berdasarkan lama pemakaian kurang dari 1 tahun telah mengalami kenaikan berat badan sebanyak 10 orang (9.71\%), sedangkan yang lama pemakaian lebih dari 1 tahun yang mengalami kenaikan berat badan adalah sebanyak 53 orang (51.46\%). Adapun akseptor yang tidak mengalami kenaikan berat badan terdapat 15 orang $(9.71 \%)$ yang lama pemakaiannya kurang dari 1 tahun dan 25 orang (30.29\%) yang lama pemakaiannya lebih dari 1 tahun.

Berdasarkan hasil uji statistik Chi Square didapatkan hasil besar nilai $X^{2}$ hitung yaitu 6.2 dan $X^{2}$ tabel dengan taraf signifikansi (a) 0.05 didapatkan hasil $X^{2}$ tabel yaitu 3.841 . Berdasarkan hasil tersebut $X^{2}$ hitung $\geq X^{2}$ tabel, yang berarti hipotesa diterima. Dengan demikian dapat disimpulkan bahwa ada hubungan antara lama pemakaian kontrasepsi suntik Depo Progestin dengan kenaikan berat badan.

Penggunaan metode kontrasepsi suntik depo progestin dapat menimbulkan terjadinya efek samping yaitu kenaikan berat badan, hal ini sesuai dengan yang disampaikan oleh banyak rujukan yang menyatakan bahwa salah satu efek samping penggunan kontrasepsi suntik depo progestin adalah terjadinya kenaikan berat 
badan, hal ini merupakan efek samping terbanyak yang dialami oleh akseptor : dibandingkan dengan efek samping lainnya yaitu terjadi perubahan pola haid berupa haid tidak teratur, perdarahan bercak/spotting, atau perdarahan sela 10 hari, mual; sakit kepala, nyeri payudara ringan, dan lain-lain. Berbeda dengan efek samping kenaikan berat badan, keluhan seperti ini akan hilang setelah penyuntikan kedua atau ketiga, sedangkan kenaikan berat badan menunjukkan kecenderungan adanya peningkatan sampai pemakaian 5 tahun, dengan jumlah kenaikan antara 2,5-7,5 kg (Sinclair, 2010).

Perubahan berat badan yang dialami pada akseptor KB suntik Depo Progestin terdiri dari bentuk gejala atau keluhan. Bentuk dan gejalanya yaitu berat badan bertanbah naik dari berat badan pada kunjungan pertama dan berat badan berkurang atau turun dari berat badan pada kunjungan pertama (Glasier,2006)

Penyebab gejala atau keluhan pada akseptor KB suntik Depo Progestin yaitu belum terlalu jelas, terjadi kenaikan berat badan, kemungkinan disebabkan karena hormon Progesterone mempermudah perubahan karbohidrat dan gula menjadi lemak, sehingga lemak di bawah kulit bertambah, selain ini hormone progesterone juga menyebabkan napsu makan bertambah dan menurunkan aktifitas fisik, akibatnya pemakaian suntikan dapat menyebabkan berat badan bertambah, peningkatan nafsu makan disertai peningkatan penimbunan simpanan lemak (Glasier,2006;102)

Meskipun penggunaan
depo progestin ini dapat
menimbulkan efek samping, namun
di Indonesia pemakaiannya

semakin popular, hal ini mungkin disebabkan karena terdapat beberapa keuntungan lain yang lebih menarik peminatnya dibandingkan dengan efek sampingnya. Keuntungan tersebut antara lain adalah KB suntik 3 bulan diketahui sangat efektif dalam mencegah kehamilan, dan merupakan program pencegahan kehamilan jangka panjang. KB suntik depo progestin juga tidak mempengaruhi hubungan suami istri dan tidak mengandung estrogen. KB suntik 3 bulan dapat digunakan oleh ibu menyusui karena tidak mengganggu produksi ASI. Akseptor KB suntik 3 bulan tidak perlu menyimpan obat suntik sendiri melainkan ibu tinggal datang ke tenaga kesehatan untuk kunjungan ulang. Suntik KB dapat digunakan oleh perempuan usia> 35 tahun sampai premenopause. Komponen yang terkandung didalamnya dapat membantu mencegah kanker endrometrium dan kehamilan ektopik, bahkan di Afrika terbukti dapat menurunkan krisis anemia bulan sabit (sicle cell) yaitu suatu penyakit genetika yang banyak ditemui di Afrika. (Prawirohardjo, 2005).

$$
\text { Jika dikaitkan dengan }
$$

beberapa teori yang peneliti gunakan sebagai sumber rujukan, maka hasil yang didapat peneliti sudah sesuai dengan teori yang ada. Menurut beberapa sumber rujukan disampaikan bahwa efek samping kontrasepsi suntik depo progestin yaitu yang berupa kenaikan berat badan, penyebabnya kemungkinan disebabkan karena hormon progesterone pada kontrasepsi suntik mempermudah perubahan karbohidrat dan gula menjadi lemak, sehingga lemak di bawah kulit bertambah, selain itu hormone progesterone juga menyebabkan napsu makan bertambah dan 
menurunkan aktifitas fisik, akibatnya pemakaian suntikan dapat menyebabkan berat badan bertambah.

\section{SIMPULAN DAN SARAN}

\section{A. Simpulan}

Berdasarkan hasil penelitian yang telah dilakukan ditetapkan sampelnya sebanyak 103 orang responden, dan dari hasil penelitian serta pembahasan yang telah disampaikan dapat ditarik kesimpulan sebagai berikut:

1. Lama pemakaian kontrasepsi suntik depo progestin terbanyak adalah yang pemakaiannya $\geq 1$ tahun yaitu sebanyak 78 orang $(75.78 \%)$

2. Akseptor KB suntik depo progestin yang mengalami Efek samping kenaikan berat badan adalah sebanyak 63 orang (61.17\%)

3. Ada hubungan antara lama pemakaian kontrasepsi suntik Depo Progestin dengan kenaikan berat badan

B. Saran

\section{1, Bagi Bidan}

Saran yang dapat peneliti sampaikan adalah lebih spesifik ditujukan kepada para bidan pada umumnya bahwa sebagai bidan praktik mandiri yang memberikan pelayanan kesehatan dasar sesuai kewenangan, hendaknya pencatatan dan pelaporan (rekam medik) dapat diisi dengan lengkap, sehingga jika ditemukan kelainan atau ada hal lain yang dibutuhkan klien maka bidan dapat memberikan umpan balik yang lebih cepat dan tepat kepada klien yang membutuhkannya. Selain itu pencatatan merupakan bagian dari kegiatan pendokumentasian yang menjadi tanggung jawab bidan untuk melengkapinya sebagai pemberi pelayanan kesehatan.

\section{Bagi Peneliti Selanjutnya}

Saran ini juga peneliti sampaikan untuk peneliti śelanjutnya bahwa penelitian ini perlu ditindaklanjuti dan dikembangkan kepada penelitian yang lebih kompleks dengan varian yang lebih kompleks dan menggunakan uji statistic yang lebih tinggi, sehingga dapat memberikan teori-teori baru yang lebih banyak demi mengembangkan ilmu pengetahuan dan teknologi yang saat ini semakin berkembang.

\section{DAFTAR PUSTAKA}

Anggraini \& Martini, (2012), Pelayanan Keluarga

Berencana,

Yogyakarta;Rohima Press

Anonim, (2005), Kapita selekta Kedokteran, Edisi Ketiga, Jakarta; Media Aesculapius FKUI.

Arikunto, Suharsimi. (2010). Prosedur Penelitian Suatu Pendekatan Praktik.Jakarta : Rineka Cipta.

Azwar, Azrul, (2014), Metodologi Penelitian Kedokteran \& Kesehatan Masyarakat, Tanggerang: Binarupa Aksara.

Benson, Ralph C \& Pernoll $M$, (2009), Buku Saku Obstetri \& Ginekologi (Handbook Of Obstetrics \& Gynecology), Jakarta; EGC

Coad, Jane \& Dunstall, Melvyn, (2007), Anatomi \& Fisiologi Untuk Bidan (Anatomy and Physiology for Midwives), Jakarta; EGC.

Glasier, Ana \& Gebbie, Alisa, (2006), Keluarga Berencana \& Kesehatan Reproduksi, Jakarta; EGC 
Hartanto H, (2004), Keluarga berencana Dan Kontrasepsi, Jakarta; Pustaka sinar Harapan.

Irianto K, (2012), Anatomi dan Fisiologi, Bandung; Alfabeta

Irianto K, (2013), Pelayanan Keluarga Berencana, Bandung; Alfabeta

Manuaba, Ida Bagus. (2010). IImu Kebidanan Penyakit Kandungan dan Keluarga Berencana Untuk Pendidikan Bidan. Jakarta : EGC.

Notoatmodjo, Soekidjo. (2012). Metodologi Penelitian Kesehatan.Jakarta : Rineka Cipta.

Nursalam, (2003), Konsep \& Penerapan Metodologi
Penelitian IImu Keperawatan, Jakarta; Salemba Medika

Prawiroharjo, Sarwono, (2005), IImu Kebidanan, Jakarta YBP-SP

Sinclair, Constance, (2010), Buku Saku Kebidanan (A Midwife's Handbook), Jakarta; EGC

Sugiyono,. (2014) Statistika Untuk Penelitian, Bandung; Alfabeta.

Sulistyawati, Ari, (2014), Pelayanan Keluarga Berencana, Jakarta; Salemba Medika

Susila \& Suyanto, (2014), Metode Penelitian Epidemiologi Bidang Kedokteran dan Kesehatan, Yogyakarta: Bursa IImu

Speroff, Leon \& Darney Philip, (2005), Pedoman Klinis Kontrasepsi, Jakarta; EGC 